\title{
BAG SKAERMEN PÅ EN DIGITAL PLATFORM
}

\author{
Kunstfærdigt integrationsarbejde og nye samarbejdskonstellationer
}

\section{SIMONE ANNA FELDING OG NETE SCHWENNESEN}

Vi vil i denne artikel undersøge det manuelle og algoritmiske arbejde, der foregår bag skærmen på en digital platform, som er designet til at afhjælpe og forebygge ensomhed. I de senere år er ensomhed kommet på dagsordenen i landets kommuner og adresseres i stigende grad som et kommunalt problem, hvilket afspejles i de mange nye indsatser, som er udviklet for at få folk til at mødes og danne nye relationer, fx seniorklubber, samtalegrupper og kaffeselskaber (Wahl-Brink et al. 2015). Ved at skabe et virtuelt mødested for kommunens borgere repræsenterer platformen et forsøg på at digitalisere sådanne kommunale indsatser.

Platformen, som vi her kalder „Venskabsportalen“, udbydes til kommuner af en privat virksomhed og finansieres af kommunerne via et abonnement. Abonnementet giver kommunens borgere fuld adgang til at oprette sig som brugere og benytte platformen gratis. Venskabsportalen fungerer som en slags digital opslagstavle: Borgere kan lave et opslag, hvor de præsenterer sig selv og efterlyser andre borgere, som har lyst til at deltage i en social aktivitet eller danne et fællesskab om en særlig interesse. Interesserede borgere kan respondere på opslaget ved at skrive et svar, som er synligt for tilmeldte brugere, eller ved at sende en privat besked til afsenderen. Hvor kontakten mange gange forbliver virtuel på mere gængse sociale medier såsom Facebook, Instagram og Twitter, er hensigten med Venskabsportalen, at den virtuelle forbindelse manifesterer sig i fysiske møder eller fælles sociale aktiviteter. I virksomhedens markedsføring af platformen lægges der ligeledes særligt vægt på, at den udgør et trygt og sikkert alternativ til mere almene sociale medier, hvor der er mindre kontrol med brugere og indhold og derved også større risiko for at opleve grænseoverskridende adfærd.

I det følgende vil vi se nærmere på det omfattende og usynlige arbejde, der foregår bag skærmen på Venskabsportalens brugergrænseflade. I et review over studier, der undersøger, hvorvidt online medieret social interaktion kan være med 
til at afhjælpe ensomhed og social isolation, konkluderer Beneito-Montagut et al., at der ikke findes stærk evidens for, hvorvidt de digitale platforme virker eller ej. Dette skyldes ifølge forfatterne, at der ikke er foretaget nok systematiske, metodisk og teoretisk grundige studier af fænomenet (Beneito-Montagut et al. 2018). I denne artikel er vi imidlertid ikke optaget af, hvorvidt platformen har den tilsigtede effekt hos brugerne. Effekt- og brugerstudier er væsentlige, men efterlader ofte det indtryk, at teknologier er stabile og tekniske entiteter, der fungerer automatisk og uden menneskelig indblanding. Vi er derimod interesseret i at belyse det menneskelige og tekniske arbejde, hvorigennem Venskabsportalen etableres og skabes i praksis. Hvor antropologer som Daniel Miller har sat fokus på, hvordan sociale medier som Facebook anvendes, tilpasses og omformes lokalt og på tværs af tid og geografi (Miller et al. 2016; Miller 2011), ønsker vi at sætte fokus på det sociale og tekniske arbejde, der former selve mediet, og den måde, det fremstår for brugerne på skærmen. Vi er her inspireret af nyere studier inden for tværfaglige videnskabs- og teknologistudier, der har sat fokus på, hvordan teknologier fungerer gennem et omfattende „,opretholdelses- og reparationsarbejde“ (Denis 2019; Schwennesen 2019a; Graham \& Thrift 2007; Henke 1999). En vigtig pointe er her, at teknologier sjældent er definitive eller afsluttede, men snarere kan forstås som skrøbelige infrastrukturer, der involverer både menneskeligt og teknologisk arbejde, og som er i konstant fare for at bryde sammen, hvis de ikke vedligeholdes og tilpasses (Denis 2019). Graham og Thrift og Henke knytter i den forbindelse an til Goffmans scenemetafor (Goffman 1959) i deres forståelse af teknologi. Hvor Goffman bruger scenemetaforen til at beskrive, hvordan selvet formes gennem forhandlinger og social interaktion med henblik på opretholdelse af en bestemt ,selv-fremstilling“ frontstage, sætter forfatterne fokus på, hvordan forestillinger om teknologier og deres effekter tilvejebringes gennem praktiske hverdagshandlinger, som både er tekniske og menneskelige. Inspireret heraf betragter vi i det følgende Venskabsportalens brugergrænseflade og virksomhedens markedsføring over for kommunerne som en synlig ,frontstage“, der fremstiller en særlig forståelse af, hvad platformen er, og hvad den kan. Vi refererer omvendt til det arbejde, der foregår bag skærmens brugergrænseflade som „backstage“, et arbejde, der er usynligt for brugerne og til dels for kommunerne, men som samtidig er helt afgørende for, at teknologien kan leve op til virksomhedens fremstilling af, hvad teknologien er, og hvad den kan. I artiklen viser vi gennem begrebet kunstfcerdigt integrationsarbejde, hvordan dette arbejde artikuleres og mobiliseres manuelt såvel som digitalt via algoritmer. Ved at fokusere på det menneskelige og algoritmiske arbejde, der foregår bag skærmen på den digitale platform, udfordres forståelsen af platformen som neutral, automatisk og teknisk. Som vi skal se, fremstår den, som andre teknologier, i stedet som en skrøbelig anordning 
af forbindelser mellem mennesker og teknologi, som kontinuerligt skal vedligeholdes for ikke at bryde sammen. Afslutningsvis diskuterer vi, hvordan der opstår et paradoksalt forhold til teknologien, når Venskabsportalen på den ene side mobiliserer en forestilling om platformen som en teknologi, der er i stand til at fungere automatisk, og på den anden side må indgå i et krævende usynligt integrationsarbejde for at få den til at indfri de forventninger, der skabes til teknologien frontstage. Hermed opretholdes forestillingen om teknologien som et teknisk og neutralt værktøj, som på ironisk vis både udgør en forudsætning og en trussel for virksomhedens forretningsmodel.

\section{Teori}

I vores analyse forstår vi Venskabsportalen som en socioteknisk infrastruktur, der muliggør, at mennesker kan få kontakt til hinanden, selv om de ikke er fysisk til stede i det samme rum. Hvor begrebet infrastruktur i daglig tale henviser til konkrete, materielle arrangementer, der muliggør, at noget eller nogen bliver transporteret gennem tid og rum, fx vejen, ledningerne, rørene, vand, information eller elektricitet, udtrykker begrebet socioteknisk infrastruktur, at infrastrukturer udgøres af et større arrangement af sociale, tekniske, politiske og diskursive elementer (Star 1999). Star beskriver, hvordan infrastrukturer ofte kan fremstå kedelige, trivielle og betydningsløse, men at de i virkeligheden er fulde af dramaer og indbyggede skjulte værdier, der kan studeres og afdækkes etnografisk (ibid.). Star opfordrer til, at vi med etnografiske metoder kan lave en strukturel omvending, ${ }^{1}$ der sætter arbejdet bag sociotekniske infrastrukturer i forgrunden og kigger nærmere på de menneskelige handlinger og beslutninger, der på trods af deres usynlighed er afgørende forudsætninger for, at infrastrukturen kan opretholdes (op.cit.385). I vores analyse laver vi en strukturel omvending, hvor vi sætter arbejdet bag skærmen af platformen i forgrunden og undersøger de værdier og handlinger, platformen skabes og formes igennem. Gennem begrebet kunstfordigt integrationsarbejde viser vi, hvordan dette „backstagearbejde“ artikuleres og mobiliseres manuelt såvel som digitalt via algoritmer. Vi er her inspireret af Lucy Suchman (1996), som bygger videre på Stars opfordring og beskriver arbejdet bag en socioteknisk infrastruktur som artikuleringsarbejde. Suchman definerer artikuleringsarbejde som ,de vedvarende bestræbelser på at føre usammenhængende elementer - af organisering, af professionelle praksisser, af teknologier - sammen til fungerende konfigurationer" (Suchman 1996:407; egen oversættelse). De forskellige elementer i Venskabsportalens sociotekniske infrastruktur udgøres blandt andet af platformens brugergrænseflade, algoritmer, kommunale politikker, Venskabsportalens medarbejdere, platformens brugere og 
kommunale medarbejdere. Suchman bruger begrebet kunstfoerdige integrationer til at understrege, hvordan artikuleringsarbejdet skabes gennem tilpasninger og integration af infrastrukturen i en eksisterende praksis:

Udtrykket [kunstfærdige integrationer] har til formål at gøre opmærksom på aspekter af systemudvikling og brug, der har været skjult, stået i baggrunden eller i skyggen, og bringe dem frem i lyset. [...] trivielle aktiviteter, som bidrager til at inkorporere teknologier i fungerende hverdagspraksisser og vedligeholde deres funktioner (ibid.; egen oversættelse).

Denne proces, hvor det usynlige artikuleringsarbejde bringes frem i lyset, stiller værdier bag teknologierne til skue og viser det store arbejde, der ligger bag teknologierne - et arbejde, der ofte tilskrives teknologien selv og ikke de personer, der udfører det (op.cit.407-8, 420-1). Dette arbejde kan beskrives som „opretholdelses- og reparationsarbejde“, idet det foretages med henblik på at opretholde en forestilling om, hvad teknologien er, og hvad den kan (Denis 2019; Schwennesen 2019a; Graham \& Thrift 2007; Henke 1999). I dette tilfælde fremstilles teknologien som en teknisk entitet, der fungerer som et transparent og passivt virtuelt mødested for mennesker, der søger at skabe kontakt til andre. Samtidig med at teknologien søges stabiliseret gennem et omfattende integrations- og reparationsarbejde, som vi skal se i det følgende, er det vigtigt at understrege, at infrastrukturen er skrøbelig og altid i fare for at bryde sammen. Jensen og Morita argumenterer i den forbindelse for, at infrastrukturer kan betragtes som eksperimentelle arrangementer, hvorigennem nye konfigurationer mellem mennesker og teknologi skabes, hvorfor vi aldrig kan vide, hvilken effekt teknologien har (Jensen \& Morita 2017). Der er derfor et potentiale for forandring, når nye teknologier integreres i en allerede eksisterende infrastruktur, men på hvilken måde og med hvilken effekt er bestemt af den konkrete og specifikke praksis, hvorigennem det sker. Med dette analytiske udgangspunkt vil vi i det følgende synliggøre det kunstfærdige integrations- og reparationsarbejde, som finder sted bag skærmen på Venskabsportalens brugergrænseflade.

\section{Baggrund og metode}

Venskabsportalen er udviklet af en dansk virksomhed, som de seneste seks år har udbudt den til kommuner i Danmark. Venskabsportalen er løbende blevet justeret og udviklet, blandt andet gennem offentlig-private innovationssamarbejder (OPI) mellem virksomheden og forskellige kommunale partnere. Platformen er således delvist et resultat af den danske stats aktuelle massive investeringer i samarbejdsog udviklingsprojekter mellem private virksomheder og offentlige institutioner. 
Forventningen er, at disse investeringer på sigt vil blive en økonomisk rentabel investering for den danske stat ved ikke bare at gøre det muligt at levere bedre og mere effektivt velfærdsarbejde gennem digitalisering, men også at udvikle teknologier og digitale løsninger, som gennem eksport og salg på et globalt marked kan skabe øget vækst og velstand i det danske samfund (Schwennesen 2019b).

Artiklen bygger på et samarbejdsprojekt mellem virksomheden og forskere ved Center for Sund Aldring, Københavns Universitet, som forløb i 2018-2019. Projektet havde fokus på, hvordan Venskabsportalen opleves, tilgås og bruges $\mathrm{i}$ to samarbejdskommuner i Storkøbenhavn: blandt medarbejdere i kommunerne, blandt brugere over 65 år i de to kommuner samt af virksomheden selv. Formålet var at give virksomheden en bredere forståelse af denne målgruppe og deres eget arbejde med platformen, som de kan bruge til den fremtidige udvikling af platformen. ${ }^{2}$

Det etnografiske feltarbejde blev foretaget af Felding over seks måneder i vinterhalvåret. Felten er etableret ved at følge de forbindelser, platformen etablerer til forskellige aktører (kommunale medarbejdere, medarbejdere i virksomheden, brugere) på forskellige lokationer (kommune, virksomhed, private hjem, online). I de to kommuner er der udført interviews med seks medarbejdere, deltagerobservation ved fire kommunalt arrangerede begivenheder og tre forebyggende hjemmebesøg. ${ }^{3}$ Hos virksomheden er der udført to interviews og deltagerobservation cirka en dag om ugen i hele projektperioden. Blandt brugerne er der foretaget ni interviews, som er foregået i interviewpersonernes private hjem. Rekrutteringen af interviewpersoner har været en blanding af purposive sampling og snowballing (Bernard 2011:145-9): Kommunerne og deres medarbejdere er udvalgt og kontaktet i samarbejde med virksomheden, virksomhedens medarbejdere er udvalgt ud fra deres arbejdsområde, og rekrutteringen af brugere er foregået ved at skrive direkte på Venskabsportalen, ved at rekruttere til kommunale begivenheder samt gennem henvisning fra virksomhedens medarbejdere.

Herudover har Felding foretaget onlinefeltarbejde, primært på Venskabsportalens hjemmeside samt på virksomhedens profiler på Facebook, Instagram og LinkedIn. Kingod beskriver i sit studie af onlinegrupper for type 1-diabetikere på Facebook, hvordan mediet både blev en kilde til rekruttering, data om hendes informanter og en felt for deltagerobservation (Kingod 2018:82). På samme måde har Venskabsportalen både fungeret som rekrutteringskilde, givet baggrundsdata og været et sted, hvor der kunne udføres onlinedeltagerobservation. Løbende i projektperioden er dette onlinefeltarbejde blevet dokumenteret gennem screenshots fra Venskabsportalen, der efterfølgende er blevet kodet på lige fod med andet empirisk materiale. Det samlede materiale udgør således transskriberede interviews, feltnoter og screenshots fra onlinedeltagerobservation. I artiklen brug- 
es primært empirisk materiale fra deltagerobservation og interviews med virksomhedens medarbejdere. Det resterende empiriske materiale har givet os en baggrundsforståelse, som har været vigtig for vores analyse, men bruges kun implicit i denne artikel.

Feltarbejdet er således ikke defineret af et fysisk sted eller en særlig gruppe af mennesker, men af fænomenet Venskabsportalen og de forbindelser, platformen skaber og virker gennem på tværs af tid og sted (Hine 2015:65-66). Felten er på mange måder sammensat og spredt, hvilket er karakteristisk for onlinefeltarbejder (Albris \& Wahlberg 2018:264). Albris og Wahlberg bruger begrebet webnografi til at beskrive digitale studier, hvor antropologer: ,studere[r] netværksemner ved at følge forbindelser online“ (op.cit.261), hvor det digitale både udgør konteksten for studiet og er det studerede objekt. Mens webnografi er karakteriseret ved primært at foregå online, har dette feltarbejde fulgt forbindelser både offline og online. Det er imidlertid ikke let at skelne mellem det digitale og det analoge (op.cit.261-4), da de forbindelser, vi analyserer, går på tværs af det analoge og det virtuelle, og den online og offline felt overlapper, influerer og henviser til hinanden. Felten findes online på Venskabsportalen samt andre platforme og offline på virksomhedens kontor, i borgernes hjem, på kommunale kontorer, på cykelture med kommunale medarbejdere og til kommunale begivenheder. Felten er også samtidig online og offline, idet Felding har brugt think-aloudmetoden til, i samarbejde med borgere og medarbejdere i virksomheden, at gennemgå platformen og dens funktioner (Kingod 2018:76-7).

Jöhncke argumenterer for, at alle feltarbejder er en samarbejdsrelation, og at relationen i nogle tilfælde kompliceres af, at vores samarbejdspartnere både indgår som en del af felten, vi undersøger, og er professionelle partnere i projektet (Jöhncke 2018:125-8, 135). Samarbejdsrelationen til virksomheden bærer netop præg af denne dobbelthed; den har været produktiv og skabt nye muligheder for i fællesskab at finde interessante perspektiver, men har også skabt friktion, når det antropologiske blik er gået fra at være professionel partner til at lægge et konstruktivt kritisk blik på arbejdet (ibid.). Under feltarbejdet har det derfor været vigtigt gentagelsesvist at gøre opmærksom på Feldings rolle som feltarbejder i virksomheden, blandt andet gennem italesættelse af hendes rolle som forsker og ved praktisk at illustrere dette ved feltnoteskrivning og ved interviews. Vi har haft særlig opmærksomhed på at afstemme forventninger undervejs ved løbende at præsentere virksomhedens leder for empiriske indsigter. Projektets indsigter er præsenteret for virksomheden og udgivet i en projektrapport, hvor fokus på brugernes oplevelser ved at anvende portalen har været $\mathrm{i}$ fokus. Her viste undersøgelsen, at mange af de ældre brugere var glade for platformen, der gav dem anledning til at mødes med andre, hvilket i nogle tilfælde udviklede sig 
til venskaber. I denne artikel er vores vidensinteresse derimod en anden. Her er vores afsæt at belyse det omfattende menneskelige og algoritmiske arbejde, der foregår bag skærmen på den digitale platform og herigennem bidrage til en mere generel problematisering af den udbredte forestilling om, at teknologier er neutrale og tekniske entiteter, som fungerer uden menneskelig indblanding, og som kan implementeres på tværs af kontekster som standardiserede pakkeløsninger. Herudover er studiet en påmindelse om, at digitale platforme, som for mange umiddelbart opleves som neutrale og transparente, er tilrettelagt og formet af mennesker og algoritmer.

\section{At skaffe brugere gennem promoveringsarbejde}

I det følgende betragter vi Venskabsportalen som en socioteknisk infrastruktur, der potentielt kan forbinde mennesker på tværs af tid og sted. Et af de helt grundlæggende elementer i infrastrukturen er, at platformen har brugere, der er aktive. Hvis der ikke er brugere og aktivitet på platformen, bryder den sammen og har ingen funktion og derfor ingen værdi for kommunerne. Hermed er forudsætningen for at kunne sælge Venskabsportalen til kommunerne ikke længere til stede, og virksomheden vil ikke kunne opretholdes på længere sigt. Antallet af brugere er da også et centralt omdrejningspunkt for virksomheden, og der er hele tiden stort fokus på ,at skaffe brugere“ i det daglige arbejde i virksomheden. Dette sker ved, at virksomheden er aktivt engageret $i$ at promovere platformen og rekruttere nye aktive brugere - et arbejde, virksomhedens ejere selv betegner som ,en kæmpe opgave“, som efterhånden er blevet den primære arbejdsopgave blandt virksomhedens medarbejdere. En af virksomhedens ejere beskriver her, hvordan det er kommet bag på ham, at det er nødvendigt at bruge så meget tid på promovering af platformen:

Vi troede [da vi startede platformen], at vi skulle være support og udvikle [platformen], men ikke, at vi skulle sælge og udbrede [...] Før arbejdede vi 80 procent med salg til kommuner og 20 procent med at få brugere ind. Nu er det omvendt. Det er en kæmpe opgave. [...] Det koster penge. Vi bruger mange penge på det her (feltnoteuddrag 19.10.18).

Promovering af platformen består af både offline- og onlinebegivenheder. Offlinepromovering foregår eksempelvis på skoler og biblioteker, hvor der uddeles gratis markedsføringsmateriale og arrangeres events, gennem uddannelse af kommunens medarbejdere, i diverse medier som aviser, fjernsynsprogrammer og lokalaviser og gennem et utal af flyers, der uddeles i de medvirkende kommuner. Onlinepromovering foregår primært gennem annoncer på Google og 
Facebook, men også ved brug af sociale medier, gennem konkurrencer og gennem samarbejder med blandt andet patientforeninger og museer. De forskellige promoveringskanaler har direkte indflydelse på væksten i antallet af brugere og på, hvilken profil brugerne har: Uddeling af markedsføringsmaterialer på skoler og gymnasier giver hurtigt mange unge brugere, mens deltagelse i kommunale begivenheder målrettet seniorer kun giver enkelte brugere.

Virksomhedens onlinepromoveringsarbejde er i høj grad formet af annoncer, som præsenteres online på Facebook og Google. Virksomheden køber annoncer målrettet særlige brugergrupper med opfordring til, at de bruger Venskabsportalen til særlige formål. Brugere, der kommer ind på platformen på den måde, opretter ofte opslag inden for det emne, som annoncen har fokus på, og det giver virksomheden indflydelse på nye brugeres profiler, hvilke opslag de laver, og hvad de er rettet mod. En af virksomhedens ejere siger:

Vi kan se, at vores medarbejder faktisk kan gå ind og definere og ændre indholdet på Venskabsportalen med de her annoncer. Han har lige lagt nogle forskellige annoncer op om sorg, og nu kan vi se, at der begynder at poppe opslag op, der handler om sorg. Det begynder pludselig at fylde mere på platformen. Så på den måde kan vi faktisk også styre, hvem der opretter sig som brugere, og hvilken slags opslag de laver, gennem de her annoncer (feltnoteuddrag 19.10.18).

Når Venskabsportalen gennem annoncer har indflydelse på dele af indholdet på platformen, opstår der et fokus på, hvilke brugere og opslag der er „gode“. For Venskabsportalen er det vigtigt med mange brugere, men også at få de rigtige brugere. Brugerne og deres opslags værdi tydeliggøres, da de pludselig kan opgøres i kroner og øre, idet Googles og Facebooks algoritmer viser prisen pr. bruger på hver enkelt annonce. Hvor meget succesfulde annoncer har en lav pris pr. bruger, har annoncer, der kun skaffer enkelte brugere, en høj pris pr. bruger:

To medarbejdere gennemgår deres Facebook-annoncer. Pris pr. bruger er det vigtigste tal. Det skal helst ligge omkring 10-15 kroner på Facebook. Men det er meget forskelligt. 'Du kan se her. Den her ligger på næsten 20 kroner. Det er lidt for højt. Men det er en annonce om sorg. Der er to, der er blevet brugere. Men her kan vi måske virkelig gøre noget. Her kan vi gøre en forskel for nogle, der har det svært. Så der vil vi gerne gå ind og betale lidt mere. Der er 20 kroner måske ikke meget. Det ville vi nok ikke betale for en badmintonmakker, men her kan det give mening' (feltnoteuddrag 19.10.18).

Det er her interessant at se, hvordan der opstår et hierarki i opslagene og brugerne, og hvordan virksomheden skelner mellem kvantitet og kvalitet. Kvantitet, forstået som antallet af brugere, er væsentligt, og det er altid godt, når brugertallet er højt - det ses, når Venskabsportalen er ude og dele markedsføringsmaterialer ud 
for at få mange brugere på ungdomsskoler. Samtidig er kvalitet lidt flere penge værd - det er de brugere, der kan være med til at opretholde samarbejdet med kommunerne, og det er også der, hvor Venskabsportalens medarbejdere føler, de virkelig kan gøre en forskel, hvis de kan hjælpe de mere udsatte brugere med at få det bedre. Denne dobbelthed mellem forretning og at ville gøre noget godt er allestedsnærværende for Venskabsportalen. De har startet virksomheden, fordi de gerne vil hjælpe andre, men skal også sælge et produkt til kommunerne. De tager derfor også hensyn til, hvilke brugere virksomheden vurderer, at kommunerne ønsker og prioriterer højest.

Igennem promoveringsarbejdet har virksomheden stor indflydelse på, hvem der bruger platformen. Virksomheden positionerer Venskabsportalen, når de er ude og promovere siden, og promoveringsarbejdet har derfor stor betydning for både indholdet på platformen og for, hvordan platformen opfattes af brugerne:

Det er godt med de to nyheder om Venskabsplatformen i Politiken og Go' Morgen Danmark. En medarbejder fortæller, at hun kan se, at der kommer brugere ind på henholdsvis $60+$ og $50+$. Det er virkelig godt. Der er rigtig mange kommuner, der gerne vil have de ældre ind, men de kan være lidt sværere at fă fat på [...] Dem, der opretter sig lige nu, er næsten alle sammen kvinder. De to nyheder havde fokus på kvindelige, midaldrende brugere. Medarbejderen siger, at det næste indslag bør være med mænd (feltnoteuddrag 18.12.18).

Det store promoveringsarbejde og opmærksomhed og indsats i forhold til at skaffe brugere afspejles i en løbende stigning i antallet af brugere over tid. Antallet af brugere spiller en central rolle i virksomhedens promoveringsarbejde over for kommunerne, hvor det kontinuerligt fremføres som bevis på, at Venskabsportalen gør en positiv forskel for borgere i samarbejdskommuner, og at kommunernes investering således har givet et positivt afkast.

\section{Manuelt og algoritmisk screeningsarbejde}

Ud over promoveringsarbejdet etableres Venskabsportalens infrastruktur via et omfattende manuelt og algoritmisk screeningsarbejde af hvert eneste opslag, besked og kommentar på Venskabsplatformen. For at forstå, hvordan virksomheden screener opslag, er det centralt først at forstå, hvordan en bruger kan oprette et opslag på platformen. Et opslag oprettes ved at udfylde en formular, hvor en bruger kan skrive en overskrift, en beskrivelse, uploade et billede og tilføje et geografisk område, hvor opslaget har relevans. Herefter klikker brugeren på „Opret et opslag“, hvorefter opslaget automatisk oprettes på Venskabsportalen.

Når en bruger åbner Venskabsportalen, ser han eller hun et udvalg af opslag, der er organiseret i fire kategorier: i nærheden, i regionen, i resten af landet, og 
til sidst ses foreninger. Opslagene er således organiseret geografisk og inddeles efter den kommune, brugeren selv bor i. Det udsnit af opslag, brugerne ser, er udvalgt af en randomiseret algoritme. Det betyder, at brugeren ser et udsnit af opslag, der er tilfældigt udvalgt af algoritmen inden for de enkelte kategorier. De er ikke udvalgt efter dato, relevans eller tema, men er en tilfældig blanding af alle opslag inden for området.

Når et opslag er slået op på platformen, bliver indholdet scannet af et digitalt værktøj. Der scannes blandt andet for særlige ord, der vurderes upassende. En medarbejder får automatisk en besked, hvis disse ord forekommer i et opslag, hvorefter medarbejderen straks gennemgår opslaget. Alle andre opslag gennemgås manuelt inden for cirka 24 timer. Venskabsportalen kalder denne del af deres arbejde for „screening“, og her redigeres og tjekkes opslagene for upassende indhold, der bryder med platformens retningslinjer, som ikke tillader opslag med henblik på dating eller kommercielle formål eller upassende og krænkende indhold. Tilliden til platformen er afgørende, da den er med til at adskille portalen fra andre sociale medier som $\mathrm{fx}$ Facebook:

Jeg føler mig mere usikker med Facebook. Jeg ved ikke hvorfor. Venskabsportalen, tror jeg, er et mere lukket system end Facebook. Jeg tror, det er derfor, jeg føler mig mere sikker på Venskabsportalen end på Facebook (bruger).

Screeningen foretages med henblik på, at brugerne ikke får dårlige oplevelser med ubehagelige kommentarer eller beskeder, og er med til at understøtte brugernes oplevelse af portalen som et trygt og sikkert sted, hvor de kan dele private detaljer om deres liv. Herudover foretager et par af virksomhedens medarbejdere tilpasning og justering af opslagene, så de i højere grad appellerer til brugerne. Medarbejderne tilføjer eksempelvis billeder på opslag, som er oprettet uden billeder, de læser korrektur og tilretter overskrifter og beskrivelser, de omstrukturerer beskrivelser, omformulerer sætninger og fjerner indhold. Venskabsportalens retningslinjer er i udgangspunktet simple, og screeningen foregår hurtigt, men ved nærmere eftersyn er det et kompliceret arbejde, som er rettet mod at gøre opslagene så attraktive for andre brugere som muligt, samtidig med at Venskabsportalen bibeholdes som et trygt og intimt mødested uden grænseoverskridende adfærd:

Når Sarah går ind på et opslag, skimmer hun det. Hun er først og fremmest opmærksom på, om der er et billede på. Er der ikke det, åbner hun en mappe med billeder, der er emneopdelt, for at finde et billede, der passer til opslagets indhold. Finder hun ikke, hvad hun vurderer som et passende billede, går hun online og finder et. Det overrasker mig [Felding], at der ofte er personer på billederne. Så henviser opslagets billede jo til en anden person end den, der har skrevet opslaget. Det havde jeg slet ikke forestillet mig. Når jeg sidder som bruger og kigger på 
opslagene, ser det ud, som om personen på billedet og forfatteren til opslaget er identiske. Sarah ændrer indimellem meget i teksten. Hun retter (nogle) stavefejl og skriver bedre overskrifter. Hun retter til og fjerner ting, der kan misforstås som dating: En bruger skriver, at han er en meget sød mand, der søger venner. Sarah fjerner 'meget sød'. Et andet sted skriver en bruger, at hun bor i et bestemt område og har en bil. Sarah fjerner hele sætningen. Generelt fjerner hun henvisninger til sted i teksten. Sarah lægger de 'gode' opslag i flere kommuner, hvorimod andre kun bliver i den kommune, de er oprettet i (feltnoteuddrag 8.2.19).

Som vi ser her, er der mange gråzoner i screeningsarbejdet. Det kan være svært at vurdere, hvornår indhold er romantisk, og hvornår det er venskabeligt, som det ses, når Sarah redigerer opslaget fra den meget søde mand. Venskabsportalens medarbejdere forklarer, at screeningarbejdet er med til at sikre, at opslag får svar. De ved, at opslag uden billede sjældent får svar, og tilføjer derfor billeder, og de deler opslag mellem kommuner for at sikre opslagenes synlighed og dermed øge sandsynligheden for svar. De fortæller, at det ligeledes er grunden til, at de gør overskrifter mere indbydende og tilretter sproget og indholdet $i$ opslagene:

Ida, der oplæres i screeningen af opslag, har lidt svært ved at finde ud af, hvornår opslag skal lægges i andre kommuner. Sarah forsøger at forklare, men der er mange undtagelser. Det handler både om emne, køn, alder og lokalitet. Handler opslaget om venner i København, skal den ikke lægges flere steder. Der er rigeligt med opslag med venner. Det viser sig dog senere, at dette ikke gør sig gældende, hvis det fx er et opslag i Vestjylland. Der er ikke lige så meget indhold der, og derfor skal det lægges i flere kommuner. Samtidig er folk mere fleksible i det område og laver mange ting på tværs af kommunegrænserne, forklarer Sarah. Et andet opslag er nogle mænd, der vil starte en madklub og derigennem få venner i København. Ida tænker det som venner i København og lægger det ikke andre steder. Det viser sig dog at være forkert. Sarah forklarer, at mændene er meget svære at fă fat på, så dem vil Venskabsportalen rigtig gerne have ud i flere kommuner. Madklub er også godt. Dem er der ikke lige så mange af (feltnoteuddrag 8.2.19).

Ønsket om, at alle Venskabsportalens brugere får svar på deres opslag, er ikke det eneste ræsonnement bag screeningsarbejdet. Der er ligeledes en anden logik bag arbejdet med opslagene, hvor nogle opslag vurderes som gode. Hvis et opslag vurderes som godt, tilføjes det til flere kommuner. Rent praktisk sidder medarbejderne med et lille kort over Danmarks kommuner ved siden af sig, hvor de finder samarbejdskommuner i nærheden, hvor de kan tilføje opslaget. Det er med til at give brugere i flere kommuner oplevelsen af, at det er opslag nær dem, og det giver det enkelte opslag en større rækkevidde, og dermed får brugeren større sandsynlighed for at få svar, samtidig med at det giver brugerne en oplevelse af, at der er flere opslag i deres kommune. 


\section{Et komplekst og usynligt hierarki af opslag}

Under screeningsarbejdet pågår en kompleks vurdering af, hvad der vurderes som et godt opslag, og som dermed skal opslås i mange kommuner, og omvendt, hvilke opslag der vurderes som mindre attraktive:

Sarah åbner et opslag. Det her er rigtig godt. Der er både nogle diagnoser - brugeren kæmper med nogle psykiske udfordringer - og han vil også lave sund mad. Det er rigtig godt. Den slår ud på mange forskellige områder, forklarer Sarah mig. Det lægger vi i flere kommuner. Sådan nogle cases vil kommunerne gerne have (feltnoteuddrag 8.2.19).

Der er intet tydeligt italesat hierarki mellem opslag med regler for, hvilke opslag der også lægges i andre kommuner. Men alligevel er det tydeligt, at emner som „sygdom“, „,handikap“, „,sorg“"og „ensomhed“ prioriteres højere end eksempelvis „sport" og „venner“, da de taler mere direkte ind i kommunale interessefelter. Køn har også en betydning. For eksempel er en mand, der leder efter venner, bedre end en kvinde, der leder efter venner, da der er færre mænd på platformen. Alder har ligeledes en betydning; ældre brugere er generelt sværere at få ind på platformen og derfor bedre end yngre. Geografi har ligeledes indflydelse på vurderingen af opslaget. Her er det afgørende, hvor mange opslag der er i kommunen, men også, hvilke samarbejdskommuner der ligger i nærheden, og om medarbejderne i virksomheden vurderer, at folk i området er villige til at køre et stykke vej for at mødes med andre brugere. Et konstrueret eksempel på et opslag, der vil være lavt rangeret på platformen, er en ung kvinde, der søger venner i København. Her fremkommer både emnet, køn, alder og geografi hyppigt, og det vil derfor ikke blive lagt i flere kommuner. Omvendt vil et opslag med en mere sjælden kombination som $\mathrm{fx}$ en mand med mentale udfordringer i Ringkøbing-Skjern, der søger en motionspartner, blive delt i flere kommuner, da det forekommer sjældent og flugter fint med kommunens øvrige sundhedspolitik. Diversitet er ligeledes en faktor. Det er afgørende, at der er mange forskellige opslag i alle kommuner, samtidig med at der skal være en form for balance. For eksempel ønsker medarbejderne ikke, at der er alt for mange opslag om ensomhed i en kommune, da det er vigtigt, at platformen virker tiltalende for en bred målgruppe af borgere, som har mange forskellige ønsker og behov.

Vurderingen af, hvorvidt et opslag skal tilføjes til flere kommuner, er også tæt forbundet med de kommunale samarbejdspartneres forventninger til platformen:

Vi ved, kommunerne godt kan lide at se de her ekstra svage borgere. Det er meget der, fokus ligger for kommunerne. Det er der, vi virkelig kan gå ind og gøre en forskel. Men vi kan også se, at det har langt større værdi både for os og de borgere (medarbejder). 
Medarbejderen beskriver her et samtidigt hensyn til kommunerne, brugerne og Venskabsportalen. Venskabsportalen navigerer inden for forskellige rationaler og hensyn, der nogle gange overlapper, men ikke altid. Kommunerne abonnerer ofte på Venskabsportalen for at ramme et særligt segment af borgere - oftest er platformen købt af en afdeling i kommunen, der arbejder med en specifik målgruppe, og de er derfor primært interesserede i denne målgruppe. Kommunerne har samtidig et ønske om at spare penge og forebygge sygdom og ensomhed hos borgerne og vil derfor gerne se nogle gode historier om borgere - $\mathrm{i}$ deres specifikke målgruppe - der har fået det bedre, efter at de har brugt Venskabsportalen. Brugerne ønsker at få svar på deres opslag, beskeder og kommentarer og se relevant indhold på platformen. Venskabsportalen ønsker at være en relevant platform, der kan beholde de kommunale (betalende) samarbejdspartnere, få folk til at mødes online og offline, have gode statistikker og bevare brugernes tillid til platformen. Alle disse ønsker påvirker Venskabsportalens vurderinger, når de redigerer i brugernes opslag. Officielt handler screeningen om, at brugerne får svar og ikke bebyrdes med upassende indhold, men det handler lige så meget om at efterleve kommunernes og Venskabsportalens egne krav og ønsker til platformen, så platformen kommer til at indfri det, kommunerne er blevet stillet i udsigt. Disse evalueringer af opslagene er dybt indlejrede i de medarbejdere, der screener opslag, og alt dette foregår som oftest ubemærket og i løbet af få sekunder. Som nævnt er der dog mange gråzoner i arbejdet, hvilket fører til, at de medarbejdere, der arbejder med screening, spørger hinanden til råds, når de er i tvivl om, hvordan de skal screene et opslag. Som vist i dette afsnit kræver vurderingerne da også komplekse evalueringer af forskellige logikker, hensyn og sammensætninger, der i sidste ende påvirker opslagenes synlighed og indhold på platformen.

\section{Konklusion}

I denne artikel har vi belyst det manuelle og algoritmiske arbejde, der etablerer Venskabsportalen som en socioteknisk infrastruktur, det manuelle og digitale screeningsarbejde samt online- og offlinepromoveringen af platformen. Herigennem er det blevet tydeligt, hvordan forskellige værdier og vurderinger er bestemmende for, hvordan platformen etableres online, og hvilke opslag brugerne ser på platformen. Det kræver stor opmærksomhed og meget arbejde fra virksomhedens side at udføre dette arbejde. Brugerne skaffes, opslagene oprettes, redigeres, ændres og placeres af forskellige humane og nonhumane aktører - af brugerne, af platformens design og algoritmer, af andre platformes algoritmer, af medarbejdernes daglige screening og redigering, af Venskabsportalens promove- 
ringsarbejde samt af Venskabsportalens og brugernes forventninger. Størstedelen af dette arbejde forbliver usynligt for brugerne og kommunerne, og ingen af de interviewede brugere har fortalt om eller bemærket det.

Vi har i artiklen synliggjort dette reparations- og integrationsarbejde, som i stor udstrækning optræder i den usynlige kulisse til platformen. Det er en krævende og omfattende proces, som er rettet mod, at brugere er aktive på platformen, at de får svar, at de har tillid til den, samt at kommunerne forbliver tilfredse med samarbejdet. Alt sammen med henblik på at etablere platformen som et værktøj, der får mennesker til at mødes, overbeviser kommunerne om platformens værdi og sikrer, at de fornyr deres abonnementer.

Integrationsarbejdet afslører virksomhedens paradoksale forhold til teknologi, hvor de over for kommunale kunder på den ene side mobiliserer teknologien som en singulær enhed, der er i stand til at fungere mere eller mindre automatisk og uden indblanding fra menneskelige aktører, og på den anden side må indgå i det usynlige og samtidig omfattende integrationsarbejde. Hermed opretholdes forestillingen om teknologien som et teknisk og neutralt værktøj, samtidig med at det usynlige arbejde på ironisk vis både er betingende og (kan være) undergravende for virksomhedens forretningsmodel, da det kræver bemærkelsesværdigt meget tid og opmærksomhed.

Vores indblik i det usynlige og kunstfærdige integrationsarbejde bag Venskabsportalens brugergrænseflade har ændret vores opfattelse af platformen. Når Felding under feltarbejdet efter deltagelsen i oplæring åbnede platformen, begyndte hun at overveje, hvorvidt billederne virkelig kom fra den pågældende person, om et opslag kom fra en anden kommune, og om teksten mon var blevet ændret. Platformen fremstod mindre autentisk, end før hun fik indsigt i det usynlige arbejde bag platformen, og hun havde ikke længere fuld tillid til autenticiteten af platformens indhold. Synliggørelsen medførte en (midlertidig) tillidskrise i forhold til platformen. Interessant nok har denne skepsis været fuldstændig fraværende blandt de interviewede brugere af platformen. Det er tydeligt, at brugerne har stor tillid til platformen og deler intime og nogle gange ligefrem hemmelige detaljer om sig selv - nogle anonymt, men andre med fulde navn og billeder - selv om alle opslag er offentlige. Brugerne deler detaljer om deres sygdomshistorik, udfordringer, seksualitet, ensomhed eller andre ting og skriver nogle gange ligefrem i opslaget, at de ikke har delt disse detaljer med deres venner og familie. Venskabsportalens infrastruktur fungerer altså netop i kraft af sin usynlighed.

Oudshoorn bruger begrebet teknologiske monstre til at beskrive teknologier, der er teknisk avancerede, men ikke er i stand til at tiltrække brugere og derfor bryder sammen. Dette skyldes, at det usynlige arbejde, der udføres af mennesker omkring og bag teknologien, ikke anerkendes, men forsømmes (Oudshoorn 
2008:283). Forsømmes dette arbejde bag skærmen, risikerer platformen at blive overflødiggjort og blive et teknologisk monster. For hvis den ikke længere er en platform, brugerne og kommunerne har tillid til, og ikke længere opleves som et medie, der kan skabe forbindelser mellem mennesker, mister den både brugerne og de betalende kommuner.

Screeningsarbejdet er således nødvendigt for at undgå, at Venskabsportalen bliver til et teknologisk monster. Samtidig er det afgørende, at screeningen ikke bliver så omfattende, at indholdet fremstår uautentisk og manipulerende, hvorved platformen risikerer at miste brugernes tillid. Brugerne skal både have tillid til, at de ikke møder ,upassende“ indhold, og til, at de fremstilles, som de selv ønsker det, og ikke kun, som Venskabsportalen ønsker det. Der er derved et tillidsparadoks iboende i screeningen. Screening er på en og samme tid afgørende for at opretholde platformen som et tillidsfuldt, trygt rum, hvor brugerne ikke oplever negative reaktioner på deres sårbarhed og åbenhed. Men samtidig kan screeningen også bryde den tillid, som den forsøger at bevare, ved at redigere for meget $\mathrm{i}$ indholdet og blive for synlig.

Sociale medier og internettets infrastrukturer medierer store dele af vores onlineliv. De fleste af os ved godt, at fx Google og Facebook på forskellig vis bearbejder og udvælger det indhold, vi ser, men vi er ikke nødvendigvis bevidste om, hvordan det sker, og hvilke effekter det har. Venskabsportalen er på mange måder et uskyldigt eksempel, men hvis et mindre medie som Venskabsportalen, hvis primære formål er at skabe fællesskaber og forebygge ensomhed, er opbygget med en infrastruktur, der er så ladet med værdier og moderationer, hvordan står det så ikke til med de større medier, vi bruger på daglig basis? Især når det drejer sig om platforme, der i modsætning til Venskabsportalen lever af klik og data og derfor har en enorm interesse $\mathrm{i}$ at manipulere indholdet, så interaktionen på platformen øges. Bevidstheden om det usynlige arbejde, der foregår bag de platforme, vi omgiver os med til daglig, er central for livet $i$ en digital alder, hvor disse platforme i høj grad er med til at strukturere vores adfærd og sociale liv. Dette tydeliggøres også i den stadigt stigende udvikling og brug af digitale teknologier og platforme til understøttelse af velfærdsydelser i Danmark. Her er det vigtigt, at de ellers skjulte værdisætninger og nye samarbejdskonstellationer, der opstår mellem private virksomheder og offentlige institutioner og mellem digitale teknologier og menneskeligt arbejde, bringes frem i lyset, så kommuner, borgere og virksomheder kan reflektere over værdierne og forholde sig kritisk til dem. 


\section{Noter}

1. Oversat fra structural inversion.

2. Projektet er finansieret gennem EU Regionalfonds-projektet „Copenhagen Healthtech Solutions (CHS)“ repræsenteret ved CACHET, Copenhagen Center for Health Technology. Projektets primære indsigter er udgivet i en projektrapport, og ideerne til artiklen er præsenteret på en konference (Felding \& Schwennesen 2019).

3. Forebyggende hjemmebesøg er et tilbud, der udbydes til ældre borgere i alle danske kommuner, hvor en kommunal medarbejder kommer på hjemmebesøg for at ,afklare behovet for fremtidige besøg og identificere de ældre, som har et særligt behov for en forebyggende indsats" Sundheds- og Ældreministeriet 2016).

\section{Litteratur}

Albris, Kristoffer \& Ayo Wahlberg

2018 At være online. Webnografi og digitale metoder. I: H. Bundgaard, H.O. Mogensen \& C. Rubow (red.): Antropologiske projekter. Side 261-74. Frederiksberg:

Samfundslitteratur.

Beneito-Montagut, Roser, Nizaiá Cassián-Yde \& Arantza Begueria

2018 What do We Know about the Relationship between Internet-Mediated Interaction and Social Isolation and Loneliness in Later Life? Quality in Ageing and Older Adults 19(1):14-30. DOI: 10.1108/QAOA-03-2017-0008.

Bernard, H. Russell

2011 Sampling III. Nonprobability Samples and Choosing Informants. In: H.R. Bernard: Research Methods in Anthropology. Qualitative and Quantitative Approaches. Pp. 143-55. Lanham: Altamira Press.

Denis, David J.

2019 Why do Maintenance and Repair Matter? In: A. Blok, I. Farías \& C. Roberts (eds): The Routledge Companion to Actor-Network Theory. Pp. 283-93. New York: Routledge.

Felding, Simone Anna \& Nete Schwennesen

2019 Digital Meeting Places. Creating Intimate and Safe Connections with Digital Means. Conference Paper from The Digitally Engaged Patient. København.

Goffman, Erving

1959 The Presentation of Self in Everyday Life. New York: Doubleday.

Graham, Stephen \& Nigel Thrift

2007 Out of Order. Understanding Repair and Maintenance. Theory, Culture \& Society 24(3):1-25. DOI: 10.1177/0263276407075954.

Henke, Christopher R.

1999 The Mechanics of Workplace Order. Toward a Sociology of Repair. Berkeley Journal of Sociology 44:55-81. www.jstor.org/stable/41035546.

Hine, Christine

2015 Ethnography for the Internet. Embedded, Embodied and Everyday. London: Bloomsbury Academic. 
Jensen, Casper Bruun \& Atsuro Morita

2017 Introduction. Infrastructures as Ontological Experiments. Ethnos Journal of Anthropology 82(4):615-26. DOI: 10.1080/00141844.2015.1107607.

Jöhncke, Steffen

2018 Projektets sociale relationer. I: H. Bundgaard, H.O. Mogensen \& C. Rubow (red.): Antropologiske projekter. Side 125-36. Frederiksberg: Samfundslitteratur.

Kingod, Natasja

2018 The Tinkering M-Patient. An (Auto-)Praxiographic Study of Attuning to a Life with Type 1 Diabetes through Online and Offline Support. Ph.d.-afhandling, Det Samfundsvidenskabelige Fakultet. København: Københavns Universitet.

Miller, Daniel

2011 Tales from Facebook. Oxford: Polity Press.

Miller, Daniel, Elisabetta Costa, Nell Haynes, Tom McDonald, Razvan Nicolescu, Jolynna Sinanan, Juliano Spyer, Shriram Venkatraman \& Xinyuan Wang

2016 How the World Changed Social Media. London: UCL Press.

Oudshoorn, Nelly

2008 Diagnosis at a Distance. The Invisible Work of Patients and Healthcare Professionals in Cardiac Telemonitoring Technology. Sociology of Health \& Illness 30(2):272-88. DOI: 10.1111/j.1467-9566.2007.01032.x.

Schwennesen, Nete

2019a Algorithmic Assemblages of Care. Imaginaries, Epistemologies and Repair Work. Sociology of Health \& Illness 41(1):176-92. DOI: 10.1111/1467-9566.12900.

$2019 \mathrm{~b} \quad$ Surveillance Entanglements. Digital Data Flows and Ageing Bodies in Motion in the Danish Welfare State. Anthropology \& Aging 40(2):10-22. DOI: 10.5195/ aa.2019.224.

Star, Susan Leigh

1999 The Ethnography of Infrastructure. American Behavioral Scientist 43(3):377-91. DOI: $10.1177 / 00027649921955326$.

Suchman, Lucy

1996 Supporting Articulation Work. In: R. Kling (ed.): Computerization and Controversy. Value Conflicts and Social Choices. Pp. 407-23. San Diego: Academic Press.

Sundheds- og Ældreministeriet

2016 Forebyggende hjemmebesøg. Sundheds- og Ældreministeriet. https://sum.dk/ Aeldre/Forebyggelse-paa-aeldreomraadet/Forebyggende-hjemmebesoeg.aspx Læst 6.4.2020.

Wahl-Brink, Dorit, Mia Saskia Olesen \& Christina Dige Rejkjær

2015 Ensomhed blandt ældre. Myter og fakta. København \& Aarhus: Marselisborg - Center for Udvikling, Kompetence \& Viden, Marselisborg Media. 